\title{
NOVI MUZEJ AKROPOLE
}

\author{
KRISTINA TOMC
}

20. junija letos so Atene po dolgih letih nestrpnega čakanja dobile novo znamenitost: Novi muzej Akropole. Svečane otvoritve, ki bi se morala zgoditi že v času olimpijskih iger leta 2004, se je udeležilo več kot tristo odličnikov s celega sveta, med njimi trideset državnih in ministrskih predsednikov. Med gosti sta bila tudi predsednik Evropske komisije José Manuel Barroso in slovenska ministrica za kulturo Majda Širca.

Prostor za novi muzej je že leta 1976 izbral Konstantinos Karamanlis, ki si je želel postaviti zgradbo, primerno za bogate najdbe z Akropole, saj v starem, tik ob Partenonu ležečem muzeju iz leta 1874 ni bilo dovolj prostora ne za razstavne predmete ne za številne obiskovalce. Lokacija na ulici Dionizija Areopagita jugovzhodno od Akropole je posrečena, saj je le 300 metrov oddaljena od Partenona in se lepo sklada s številnimi arheološkimi najdišči, dostop pa lajša tudi nedavno odprta postaja podzemne železnice (Акро́то $\eta$ ) v neposredni bližini. Stik s Partenonom je odločilno vplival na zasnovo ogromnega, 130 milijonov evrov vrednega projekta, ki so ga zaupali švicarsko-francoskemu arhitektu Bernardu Tschumiju v sodelovanju z Michaelom Fotiadisom. Moderna stavba s površino $21000 \mathrm{~m}^{2}$ je opremljena z vsem, kar nudijo sodobni muzeji, vendar bi v vsakem drugem mestu njen čar zbledel. Veličasten razgled in naravna svetloba omogočata pristnejši dialog z razstavljenimi predmeti in njihovim najdiščem. Poleg betona in marmorja je muzej namreč v veliki meri zgrajen iz stekla, kar je bil velik izziv za arhitekte in obenem idealna rešitev za zagato, ki jo je povzročilo odkritje obsežnih arheoloških ostankov pod površino, izbrano za gradnjo. Tschumi je uspel skomponirati fascinantno stavbo, v kateri je razstavljenih približno 4000 predmetov, kar desetkrat več kot v starem muzeju. Do konca decembra si je mogoče obisk privoščiti za en sam evro, a najbrž se v zadnjih junijskih dneh na stopnišču pred vhodom ne bi gnetlo nič manj ljudi, tudi če bi bil znesek znatno višji. Kljub vnaprej rezerviranim kartam, ki so bile v prvih dneh po otvoritvi obvezne, so se radovedni obiskovalci začeli zbirati že pred osmo uro zjutraj, ko so se odprla vrata na dvorišče in se je začelo nepozabno doživetje.

Že pred vstopom, ob katerem obiskovalce poleg stroge kontrole varnostnikov pozdravi kamnita sova, pritegnejo pozornost razvaline pod tlemi. Posebno steklo in odprt prostor, zaščiten s teraso na mogočnih stebrih, razkrivata, da smo na področju, 
ki je bilo neprekinjeno poseljeno od 5. stol. pr. Kr. vse do bizantinske dobe. Temelji muzeja stojijo med nekdanjimi ulicami, hišami, dvorišči, kopališči, delavnicami, grobovi ... Izkopavanja so prinesla številne predmete iz vsakdanjega življenja, npr. razno posodje, nakit, leščerbe, orodje, votivne kipce, otroške igrače ... Arheološke najdbe so zaznamovale postavitev pritličja in prvega nadstropja, drugo nadstropje pa je prilagojeno legi Partenona, zato je za 23 stopinj drugače zasukano. Naravna svetloba se skozi steklo razliva od vrha stavbe do temeljev.

Večji del pritličja je namenjen funkcionalnosti: tu so blagajne za nakup vstopnic, trgovina s spominki, razglednicami, plakati ..., garderoba in toaletni prostori, ki jih seveda najdemo tudi v višjih nadstropjih. Zelo dobro je poskrbljeno tudi za slabše mobilne obiskovalce, ki so jim na voljo invalidski vozički, dvigala in posebej narejen dovoz do muzeja. Nekaj prostora je odmerjenega začasnim razstavam in izobraževanju. Za najmlajše je pripravljen poseben program $\mathrm{z}$ didaktičnim gradivom, tako da pogosto naletimo ne le na skupine šolarjev, ampak tudi na zvedave malčke $\mathrm{z}$ vzgojiteljicami. $\mathrm{V}$ jedru zgradbe se prične krožna pot, ki ponazarja vzpon na Akropolo in sestop z nje. Prvi del stalne razstave je posvečen pobočjem akropolskega griča. Najdragocenejše najdbe so bile žal uplenjene, toda kljub temu sledi poselitve in manjših svetišč ne razočarajo. Engainion iz 3. stol. pr. n. št. si lahko ogledamo skozi steklo pod tlemi, $\mathrm{v}$ vitrinah na obeh straneh vzpenjajoče se poti pa je veliko glinenih izdelkov, raznih posod za različne namene, orodij, igrač, votivnih predmetov ... Ohranili so se reliefi, napisi in kipi iz Asklepijevega svetišča, v Nimfinem templju so ostale čudovite posode in kipci iz terakote, razstavljeni so predmeti iz svetišča Afrodite in Erosa, ostanki Proklove hiše, ne moremo spregledati dveh kipov boginje Nike, Silenove podobe ...

Ko se vzpnemo v prvo nadstropje, najprej zagledamo pediment Hekatompedona, prvega znanega svetišča na Akropoli. V sredini sta dve levinji, ki trgata bika, na levi strani Heraklov boj s Tritonom in na desni pošast s tremi telesi, ki v rokah držijo vodo, ogenj in ptiča, simbol zraka. Če se obrnemo, nas z balkona nasproti pozdravljajo veličastne kariatide iz Erehteiona, do katerih prispemo, ko si ogledamo čudovito zbirko iz arhaične dobe. Znamenitih podob je toliko, da je naštevanje nesmiselno: svečani

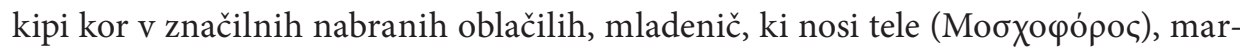
morna četverovprega, sfinge, podoba konja iz parskega marmorja, gigantomahija s pedimenta starega Ateninega svetišča s podobo boginje, plavolasi deček, Rampinov jezdec, relief žalujoče Atene, levja glava, Kritijev deček, ki spada že na začetek klasične dobe ... V vitrinah so manjši predmeti, zlasti zaobljubni darovi za Ateno. Sledijo svetišča, ki so bila zgrajena po Partenonu in jih prikazujejo tudi nazorne makete: Erehtejon s kariatidami, Propilaja z marmornato Hermesovo glavo in tempelj Atene Nike z znamenitim reliefom boginje, ki si popravlja sandalo. Eden od vrhuncev razstave so nedvomno kariatide, ki si jih zdaj končno lahko ogledamo od vseh strani in občudujemo njihove umetelne pričeske, ki dodatno podpirajo glavo 
$\mathrm{s}$ težkim bremenom. Manjkajoča kariatida je v Britanskem muzeju; prazno mesto napoveduje prizore, s katerimi se bomo srečevali v drugem nadstropju. Arhitekt je predvidel, da se bodo obiskovalci tja podali že po ogledu arhaične zbirke in tako sledili kronološkemu zaporedju, drugo polovico prvega nadstropja pa prihranili za pot navzdol. Toda večina si najprej ogleda še spomenike iz klasične, helenistične in rimske dobe, od katerih se jih je veliko izgubilo. Razstavljeni so kipi vojaških poveljnikov, cesarjev in njihovih žena, filozofov in govornikov, kopije kipov iz klasične dobe, kovanci, napisi ... Vidimo lahko npr. ogromno glavo Artemide Brauronske, glavo mladega Aleksandra Makedonskega ...

Tekoče stopnice $\mathrm{v}$ sredini stavbe nas najprej pripeljejo do mezanina, kjer je multimedijsko središče, trgovina $\mathrm{z}$ darili in literaturo o Akropoli, restavracija in kavarna. K slednjima dvema spada tudi $700 \mathrm{~m}^{2}$ velika terasa, ki se razteza nad arheološkimi najdbami, na katere gledamo skozi steklo. Še lepši je razgled na Akropolo in Partenon na njej. Terasa je bila v središču dolgotrajnega spora, saj naj bi zaradi nje porušili dve stavbi na ulici Dionizija Areopagita (št. 17 in 19), ki rahlo zastirata pogled na Partenon. Prva hiša, ki jo je leta 1930 zgradil Vassilis Kouremenos in jo krasita mozaika Tezeja ter Ojdipa in Sfinge, velja za najlepši primer art deco stila v Atenah, zato so jo leta 1988 zaščitili kot umetniško delo, sosednja zgradba, ki jo ima v lasti skladatelj Vangelis Papathanasiou, pa je neoklasicistična. Ministrstvo za kulturo je leta 2007 odobrilo rušenje, vendar je po hudih naprezanjih nasprotnikov, ki so zbrali kar 48000 podpisov proti odstranitvi hišs, vrhovno sodišče letos julija odločilo, da stavbi ostaneta. Čeprav je večina Grkov navdušeno pozdravila muzej kot najpomembnejšo kulturno pridobitev zadnjega časa in med obiskovalci srečamo ogromno ponosnih domačinov, ki sicer najbrž redko zaidejo na kako razstavo, je bilo slišati tudi kar nekaj kritik, češ da ogromna nova stavba preveč izstopa in se ne prilega svoji okolici. Gradnja muzeja je bila povod za več kot sto sodnih primerov. Večinoma gre za estetsko vprašanje, a glede na količino grških arheoloških najdišč bi bilo morda razumneje bolj pravično razdeliti sredstva in zastaviti nekoliko manj ambiciozen projekt, namenjen le enemu, pa četudi najpomembnejšemu od njih. Odločitev Grkov laže razumemo, ko se povzpnemo na vrh, $v$ drugo nadstropje muzeja.

Pravokotnik iz stekla obdaja razstavne površine, ki se prostorsko povsem skladajo s Partenonom, na katerega se odpira pogled skozi steklene stene. Tako si ni težko zamišljati, kako je svetišče izgledalo nekoč. Za še boljšo predstavo poskrbi kratek film. Gigantomahija, boj z Amazonkami, boj kentavrov in Lapitov ter trojanska vojna na metopah, veličastna procesija na frizu, na kateri je upodobljenih približno 378 človeških podob in več kot dvesto živali, predvsem konjev, kipi na pedimentih, ki prikazujejo Atenino rojstvo iz Zevsove glave ter spor med Pozejdonom in vladarico mesta, v katerem se nahajamo - vse te podobe so pod žarki grškega sonca neverjetne. Vendar užitek ni popoln, saj medeno barvo pentelskega marmorja prepogosto grobo prekinja hladna belina kopij. Od 160 metrov Fidijevega friza jih je v Atenah 50 
metrov, 80 metrov je v Britanskem muzeju, en kos imajo v Louvru, še nekaj manjših fragmentov je razpršenih po drugih evropskih muzejih, ostalo pa je bilo uničeno leta 1687 v eksploziji med benečansko-turško vojno. Akropolski muzej ima 39 metop od prvotnih 92, v Angliji jih je 15. Plen, ki si ga je v začetku 19. stol. s privolitvijo takratnega otomanskega vladarja prilastil lord Elgin in ga kasneje prodal Britanskemu muzeju, vsebuje še 17 figur s pedimentov. Kot je v svojem govoru na otvoritvi poudaril minister za kulturo Antonis Samaras, je Grčija z novim muzejem jasno pokazala, da je pripravljena na vrnitev partenonskega bogastva. Boj za Elginovo zbirko je že v osemdesetih letih začela Melina Merkouri, takratna ministrica za kulturo, vendar so jo Britanci zavrnili, češ da Grki nimajo ustreznega prostora za marmorne umetnine. Novi muzej, zlasti zgornje nadstropje, je tako tudi grški odgovor britanski vladi. Trimesečno izposojo, ki bi vključevala priznanje britanskega lastništva, so Grki odklonili in samo sprašujemo se lahko, kako čudovito bi bilo, če bi si lahko nekoč vse zaklade z Akropole ogledali na enem mestu. ${ }^{1}$

Do takrat si lahko partenonski friz ogledujemo in se z njim igramo na naslednji spletni strani: http://parthenonfrieze.gr. Domača stran novega muzeja pa je: http://www.theacropolismuseum.gr. 